\title{
ОСОБЕННОСТИ ЦЕНЗУРЫ И САМОКОНТРОЛЯ СМИ В ПРОЦЕССЕ ФОРМИРОВАНИЯ ДЕМОКРАТИЧЕСКОГО ОБЩЕСТВА
}

\section{CHARACTERISTIC OF MEDIA CENSORSHIP AND SELF-CONTROL IN THE PROCESS OF FORMING A DEMOCRATIC SOCIETY \\ V. Torosyan \\ M. Borovik}

Summary: The article examines the controversial role of the mass media in the formation of a democratic society, when instead of officially abolished censorship, the need for self-control and appropriate moral criteria becomes especially urgent. On the one hand, the mass audience of the media and their efficiency in resonant coverage of a wide range of events allows us to solve serious problems. On the other hand, sometimes the freedom of the media understood as permissiveness, turns into a scandal, the education of a bad taste of the audience, moreover, threatens the stability of the state. Methods of comparison and analysis of wellknown news materials prove the urgent need to determine reasonable and fair restrictions in the practice of the media. It is proved that this problem is directly related to the cultural policy of the state, which can't be based longer on prohibitions and compulsions, but should take the character of a long-term program of cultural education.

Keywords: mass media, law, restriction, censorship, force, prohibitions, self-control.

\author{
Торосян Вардан Григорьевич \\ Д.ф.н., профессор, Краснодарский государственный \\ институт культуры \\ torosyan5@mail.ru \\ Боровик Мария Викторовна \\ Аспирант, Краснодарский государственный \\ институт культуры \\ borovik_maria@mail.ru
}

Аннотация: В статье рассматривается противоречивая роль средств массовой информации в условиях формирования демократического общества, когда вместо официально отменённой цензуры становится особенно актуальной необходимость самоконтроля и соответствующих нравственных критериев. С одной стороны, массовость аудитории СМИ и их оперативность в резонансном освещении широчайшего спектра событий позволяет выносить на обсуждение и решать серьёзные проблемы. Вместе с тем свобода СМИ, порой понимаемая как вседозволенность, оборачивается скандальностью, воспитанием дурновкусия аудитории, более того, угрожает стабильности государства. Методами сравнения и анализа известных новостных материалов доказывается острая необходимость определения разумных и справедливых ограничений в деятельности СМИ. Доказано, что указанная проблема имеет прямое отношение к культурной политике государства, которая не может больше строиться на запретах и принуждениях, а должна принять характер долгосрочной программы культурного воспитания.

Ключевые слова: средства массовой информации, закон, ограничение, цензура, принуждение, запреты, самоконтроль.

В статье с помощью социального, исторического и культурологического подходов рассмотрены основные сферы влияния прессы на общество с особым вниманием к анализу и сравнению реакций реципиентов СМИ на те или иные публикации, приведенные в привязке с недавно вышедшими законами РФ, касающиеся работы прессы, статьями в официальных средствах и комментариями общественных деятелей. Использование свежих новостных материалов позволит раскрыть неоднозначные проблемы цензуры и самоконтроля СМИ.

Многовековая история средств массовых информаций всегда была тесно связана с общественно-политической жизнью общества. Еще в эпоху Римской империи Юлий Цезарь осознал необходимость освещения важных сведений о государственной жизни. Было создано первое рукописное периодическое издание протоколов сената Acta senatus, которое стало первым массовым словом, стимулирующим в дальнейшем появление газет и книг. Должность цензора в Древнем Риме была учреждена значительно раньше, чем появление издания (в 443 году до н.э.) и первоначально регулировало налоги-подати и военную деятельность. Веками позже первые га- 
зеты появились там же, на территории Италии, и получили название по монетке, которыми они оплачивались.

В России только в петровское время (указ Петра I от 15 декабря 1702 года) возникло первое периодическое издание под заголовком «Ведомости Московского государства», которое чуть позже - через две недели получило привычное для нас название «Ведомости» (2 января 1703 год). Средства массовой информации с самого начала были под строгим надзором: Императоры и Синод православной церкви наблюдали за публичным словом. Позже эту функцию передали профессорам Петербургской Академии наук и Московского Университета. Цензура в то время стала неотъемлемой функцией государства. С её помощью реализовали систему запретов и ограничений, а также механизм пропаганды.

С появлением советской власти цензурный пресс и вовсе носил жесточайший характер. Например, в 1937 -1938гг. редакторов, журналистов, писателей, подвергшихся цензуре за свободомыслие, - репрессировали. Были арестованы известные публицисты и режиссеры, а их работы на долгое время положены «на полку».

Жестокая цензура и преследование деятелей искусства, не вписывающихся в рамки партийной идеологии и «социального реализма», продолжались даже в период «Хрущевской оттепели». Вошли в историю две выставки, получившие всемирный резонанс и разгромленные властями. Это выставка художников-авангардистов в московском Манеже и «бульдозерная выставка» в Измайловском парке. При посещении их Никита Хрущев подверг экспонаты и самих художников жесткой критики, использовав нецензурные выражения. Следующим примером можно назвать вынужденный отказ Бориса Пастернака от Нобелевской премии, в результате массовой кампании давления. Были изгнаны из СССР Александр Солженицын и приютившие его на своей даче Мстислав Ростропович и Галина Вышневская, через непростые коллизии прошел автор «Тихого Дона», покончил самоубийством принуждаемый к роли идеологического цензора председатель Союза писателей СССР Александр Фадеев.

Только при правлении Михаила Горбачева получили «зеленый свет» пролежавшие десятилетия на полке художественные произведения и кинофильмы, началось постепенное освобождение от цензурного давления, которое завершилось отменой шестой статьи Конституции о руководящей роли КПСС и принятием закона о СМИ (1991г.). Впервые стали транслировать по радио и телевидению съезды КПСС. Помнится, однако, как тот же Михаил Горбачев кричал на предавшего огласке нелицеприятные факты нашей политики академика Андрея Сахарова, который в тот же вечер скончался от инфаркта. Как бы то ни было, одним из ощутимых результатов «перестройки» оказались невиданная доколе свобода и «зубастость» СМИ, которые многократно обсуждались в русской литературе. Появились и не испытанные ранее трудности - жизнеобеспечения. По причине нехватки финансовых средств подавляющее большинство СМИ осталось без финансирования. Под опекой государства были, в основном, те издания и медиа-холдинги, которые защищали интересы новой власти. Остальным же нужно было искать инвесторов. Сражаясь за «хлеб», многие СМИ стали забывать об этике, самоконтроле и подлинности информации, что повлекло за собой ряд проблем: распространение вредоносных идей, отсутствие полного контроля к призывам экстремизма, конфликты на духовно-нравственные темы, выходящие далеко за рамки приличия материалы.

И тут возникла уже в новом ракурсе проблема возможности цензурных ограничений на пути к демократии. Этот вопрос актуален и всегда вызывал непримиримые споры общественных деятелей и массу противоречивых мнений. С одной стороны, в современном обществе с появлением такого рычага контроля возможно злоупотребление им в виде ограничения свободы выражения мысли и развития общества в сферах культуры, искусства и науки. С другой же стороны, благодаря ограничениям можно избежать множества конфликтов в обществе, а также контролировать информацию по духовно-нравственному аспекту.

Не случайно, средства массовой информации считаются четвёртой ветвью власти и имеют сильное влияние в обществе. Многие события в политической, экономической, общественной и культурной жизни освещаются через СМИ. Масс-медиа стали важной частью системы социализации людей, играют важную роль в формировании общественного мнения, задают стандарты жизни и сознания. В обстановке затянувшейся в России переоценки ценностей заметны две противоположные тенденции - серьёзное, ответственное освещение событий и скандальность, пренебрегающая и даже демонстративно нарушающая нормы нравственности. Сюжеты, особенно на телевидении, оказываются вовлеченными в некий весьма опасный порочный круг - производитель низкопробной продукции оправдывается тем, что таков запрос потребителя - массовой аудитории, а это гарантия дальнейшей деградации культуры населения, которая может принять масштабы неконтролируемого, лавинообразного, разрушительного национального бедствия.

Средства массовой информации являются важной частью жизни политиков, и не только во время предвыборной гонки. Например, тяжелая ситуация на Украине во многом подогревается благодаря «информационной войне» и отсутствию какого-либо контроля в прессе. Пропаганда еще задолго до Майдана готовила зрителей 
к такому исходу. В России тоже были демонстрации на почве национальных различий в 2012 году. Однако без поддержки прессы эти волнения не получили бы такой громкой огласки.

Ухудшение условий жизни в период пандемии стало неким катализатором активной законотворческой деятельности российских политиков. Четырехмесячный карантин увеличил рейтинг СМИ в обществе и, как следствие, его контроль. Среди самых обсуждаемых законов можно выделить поправки в статью 13.15 КоАП РФ «Злоупотребление свободой массовой информации». Теперь прописана административная ответственность за распространение фейковых новостей. Вышел закон о клевете в интернете (изменения в статье 128.1 УК РФ), который предусматривает не только штраф до 1 миллиона рублей, но и лишение свободы на срок до двух лет. Еще был изменен закон «Об информации, информационных технологиях и о защите информации». Теперь журналистов, освещающих несанкционированные акции, в некоторых случаях можно приравнять к протестующим. Закон ужесточает порядок участия СМИ в публичных мероприятиях, при этом работник прессы на митингах обязан использовать «знак (признак)» представителя прессы. Весьма противоречивую реакцию общественности вызвал только готовящийся закон о просветительской деятельности, который при соответствующем истолковании может означать возврат к идеологической цензуре. Интересно, что три года назад главный редактор «Эха Москвы» Алексей Венедиктов в одном из интервью сделал три предсказания, которые сейчас уже стали действительностью. Это законы, ограничивающие интернет, уменьшение количества оппозиции и внешняя изоляция.

Наряду с этим, в современных средствах массовой информации реализовываются немыслимые в советское время вещи - поднимаются важные экологические и общественные проблемы, пресса способствует разоблачению коррупции. Такова, например, скандальная история с судьей из Краснодара Елены Хахалевой. После ряда видеосюжетов на НТВ ее деятельность и соответствие занимаемой должности проверялись в следственных органах, после чего Елена Хахалева была выведена из состава президиума Краснодарского краевого суда.

В современных средствах массовой информации при этом нередко наблюдается прямолинейность поддержки государственных решений, как, например, с пенсионной реформой. С одной стороны, честно объяснена экономическая неизбежность данного решения, a, с другой - доверие к прессе подрывает показ «счастливых пенсионеров». Здесь прослеживается метод манипулирования массовым сознанием, который называется: свидетельство «простых смертных» [5. Раздел 3 Гл. 2 С. 9].
Зачастую не только освещаются, но и происходят конфликты в СМИ на религиозной почве. В России, по данным министерства Юстиции 2019 года, зарегистрировано более 30 тысяч религиозных организаций. Среди работников прессы в современном обществе эта тема вызывает большой интерес. Призывы общественных деятелей в борьбе за нравственность не смолкают в заголовках СМИ.

Широкое обсуждение в прессе позволило найти компромиссные решения такой проблемы как: передача религиозным организациям соборов и художественных произведений (картин), которые находятся в государственной собственности. Существующий закон позволяет церкви иметь права на религиозные объекты, однако громкие скандалы позволили скорректировать влияния на них.

Среди последних конфликтов на религиозную почву можно выделить крайне негативную реакцию на публично высказанное одобрение со стороны Ксении Собчак решения французского президента Эммануэля Макрона о продолжении работы скандального карикатурного издания Charlie Hebdo. Неуважение деятелей журнала к религиозным ценностям повлекли непоправимые последствия - 13 человек убито во Франции из-за конфликтов после просмотра карикатур издания.

Другим примером можно назвать общественный конфликт в отношении фильма «Матильда» Алексея Учителя. Депутат Госдумы РФ Наталья Поклонская обращалась в Генпрокуратуру с просьбой проверить фильм на предмет оскорбления чувств верующих, приложила немало усилий для запрета кинокартины, аннулировании лицензии на прокат. Однако позже сама призналась, что совершила ошибку. Такое необдуманное поведение, повлекшее за собой травлю создателей фильма, поджоги кинотеатров, пикеты, осуждалось в средствах массовой информации.

Последнее десятилетие ознаменовалось чередой громких скандалов, которые дали повод для дискуссий об отношении к религии в современном обществе. Например, срыв выставки Марата Гельмана в Краснодаре, закрытие оперы «Тангейзер» в Новосибирске, убийство голландского режиссера Тео Ван Гога, карикатурные скандалы в Дании и Франции. Со свободой слова повышается и ответственность. Радикальные взгляды религиозных фанатиков зачастую к самой вере не имеют ничего общего. Однако провокационное искусство способно стать катализатором для противоправных действий. В решении этой проблемы необходимо соблюдать принципы взаимного уважения. Характерной тенденцией становится то, что СМИ обеспечивают возможность высказывания разных сторон обсуждения самых острых проблем. 
Впервые идея о саморегулировании журналистского сообщества появилась в Европе и США на рубеже XIX и XX веков. Это было связано с образованием крупных газетных монополий, которые получили в свои руки все инструменты манипулирования читателем и стали беспрепятственно ими пользоваться. Так в середине 1940-х гг. в США появилась Комиссия Хатчинса (официальное название Комиссия по Свободе печати), которая 4 года изучала современное состояние свободы и ответственности американских СМИ. В итоговом докладе они определили главные принципы ответственности прессы, которые легли в основу системы саморегулирования СМИ во всем мире.

Главный вывод, сделанный Комиссией: если современному обществу требуются крупные органы массовой коммуникации, которые представляют угрозу для демократии, - эти органы должны перейти на саморегулирование, в противном случае их будет контролировать правительство. Данный вывод можно назвать первым высказанным учеными обоснованием необходимости самоконтроля в прессе, так как иначе выход будет один - тотальная цензура СМИ.
В современной России действует Кодекс профессиональной этики российского журналиста, который был принят Конгрессом журналистов России 23 июня 1994 года. Он предназначен для членов Союза журналистов России, однако не каждый деятель прессы входит в его состав.

Подводя итог, можно с уверенностью сказать, что бесконтрольность СМИ опасна и разрушительна для общества, грозя не только дурновкусием но и социальным напряжением. Задача современного общества состоит в том, чтобы найти компромисс, определить, какие ограничения являются разумными и справедливыми, а какие - нет. Безусловно, эта задача должна занимать весьма важное место в культурной политике государства. Существующее положение дел убеждает при этом, что юридическое решение проблемы может носить лишь тактический, ограниченный текущим моментом характер, а в стратегической, долгосрочной перспективе культурная политика должна базироваться на всеобъемлющей программе воспитания населения, обеспечивающей широкий кругозор, усвоение веками традиционных культурных ценностей, гражданскую ответственность.

1. Авраамов Д.С. Профессиональная этика журналиста - М.: МГУ. 2003.

2. рабельников А.А. Русская журналистика на рубеже тысячелетий. Итоги и перспективы - М.: Издательство РИП - холдинг, 2001 - 183 .

3. Грабельников А.А. Средства массовой информации постсоветской России: пятнадцать лет спустя: Монография - М.: РУдН, 2008. - 341 с.

4. Горяева Т.М. Политическая цензура в СССР. 1917-1991. - М.: «Российская политическая энциклопедия» (РОССПЭН), 2009. 8-9 С.

5. Дзялошинский И.М. Российские СМИ в избирательной кампании: уроки эффективности - М: Студия «Викон», 1996.

6. Дзялошинский И.М. Современное медиапространство России: Учеб. пособие для студентов. - М.: Издательство «Аспект Пресс», 2015. —312 с.

7. Евдокимов В.А. Региональные печатные СМИ как субъект политического конфликта (на примере Омской области) // Сборник статей «Журналистика и политика» - Екатеринбург, 2004 - 30 c.

8. Жирков Г.В. История цензуры в России XIX-XX века. // Аспект-Пресс, 2001.

9. Карпук Д.А. Духовная цензура в России по второй половине XIX в. (по материалам фонда Санкт-Петербургского духовного цензурного комитета) // Научная статья. Христианское чтение №2. 2015. 1 - 20 с.

10. Лунцова Н.Р. Функционирование СМИ в политическом процессе (На материале федеральных печатных СМИ): Дис. ...: канд. полит. наук. Екатеринбург, 2003. $145 \mathrm{c}$.

11. Мамонтова 0.И. Развитие основных институтов саморегулирования СМИ в мире // Вестник Московского университета Серия 10. Журналистика. Научная статья - М.: МГУ. 2010.

12. Минаева 0.Д. Русская журналистика в документах: История надзора / под ред. Б.И.Есина, Я.Н.Засурского. - М.: Аспект Пресс, 2003. - 397 с.

13. Рейфман П.С. Цензура в дореволюционной, советской и постсоветской России: в 2 т. Т. 1: Цензура в дореволюционной России. Вып. 3: 1855 - 1917 гг. / науч. ред. Е.С. Сонина, библиогр. ред. Н.В. Градобоева; пред. И.А. Пильщикова и В.С. Парсамова. — М.: «Пробел-2000», 2017. — 305 с.

14. Свободная и ответственная пресса/под ред. М.И. Макеенко - М.: ВК, 2005. - 72 с.

15. Хатчинс Р.М. Свободная и ответственная пресса / пер. Н.Е. Евдокимовой, под ред. М.И. Макеенко. — М.: Икар, 2005.

( Торосян Вардан Григорьевич (torosyan5@mail.ru), Боровик Мария Викторовна (borovik_maria@mail.ru). Журнал «Современная наука: актуальные проблемы теории и практики» 